\title{
Mladi u vremenu krize
}

\section{Institut za društvena istraživanja u Zagrebu i Zaklada Friedrich Ebert, 2013., 175 str.}

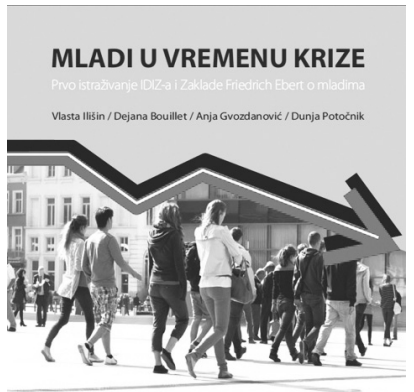

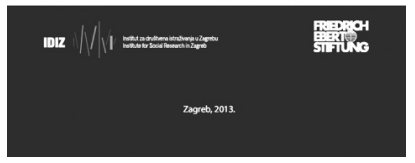

Knjiga Mladi u vremenu krize u izdanju Instituta za društvena istraživanja u Zagrebu i Zaklade Friedrich Ebert donosi pregled podataka o mladima u Hrvatskoj koji su prikupljeni u srpnju 2012. godine, a istraživanje je bazirano na dugogodišnjem Shellovom istraživanju mladih. Autorice su knjige Vlasta Ilišin, Dejana Bouillet, Anja Gvozdanović i Dunja Potočnik, koje svojim iskustvom u prijašnjim istraživanjima mladih i znanstvenim usmjerenjem predstavljaju garanciju kvalitete i pouzdanosti koja je bila potrebna za takav obuhvatan projekt. Predgovor knjizi napisao je voditelj regionalnog ureda Zaklade Friedrich Ebert u Zagrebu, a iznimno pozitivne i bogate komentare pružili su recenzenti - Klaus Hurrelmann, voditelj Shellovih istraživanja mladih u Njemačkoj, dr. sc. Furio Radin i prof. dr. sc. Vedrana Spajić-Vrkaš.

Može se reći da se istraživanje temelji na dvjema tradicijama istraživanja. Kao prvu bih istaknuo, već spomenuto, Shellovo istraživanje mladih (Shell Youth Survey), koje se od 1953. godine provodi u Njemačkoj, a zatim je prošireno i na niz zemalja u Europi, ali i izvan Europe. Naravno, ta tradicija zauzima primarno mjesto jer je koncepcija pitanja i provedba istraživanja temeljena upravo na njoj, a i pruža osnovu za komparativna istraživanja. Kao drugu tradiciju istaknuo bih niz istraživanja mladih koja su u Hrvatskoj provedena od 1980-ih godina do danas. Ta tradicija pokazuje kontinuitet istraživanja i važnost ove teme u domaćoj znanstvenoj i istraživačkoj zajednici, ali i potencijal za longitudinalna istraživanja trendova među mladima.

Prije prikaza knjige po poglavljima i kritičkog osvrta potrebno je predstaviti definiciju mladih, hipoteze od kojih autorice polaze i metode koje su koristile u ovom istraživanju te uzorak koji je pokriven. Istraživanjem se pokrivaju mladi u dobi od 14 do 27 godina (rođeni između 1985. i 1998. godine), a obuhvaćeno je 1500 ispitanika. Polazi se od dviju hipoteza: „1. da su mladi po svom načinu života, stavovima, vrijednostima i obrascima ponašanja prepoznatljiva društvena skupina; 2 . da se u tom pogledu različiti segmenti mladih međusobno razlikuju s obzirom na njihova sociodemografska obilježja“ (str. 13). Kod prikupljanja podataka korištena je CAPI 
metoda (engl. Computer assisted personal interviewing), a obrada podataka vršena je kroz SPSS te je obuhvaćala univarijatnu, bivarijatne i multivarijatnu analizu. Kako bi se omogućilo diferenciranje mladih na različite segmente, čija je razlikovnost pretpostavljena u drugoj hipotezi, koristilo se šest sociodemografskih obilježja: spol, dobna kohorta, rezidencijalni status, socioprofesionalni status, stupanj obrazovanja ispitanika i stupanj obrazovanja ispitanikova oca. Uz to, istaknute su i specifičnosti s kojima se autorice susreću. One se očituju na dvjema razinama - na razini tranzicijskih društava te hrvatske specifičnosti. Prve se tiču fenomena dvostruke tranzicije koja obuhvaća prelazak „iz djetinjstva u odraslost u društvima koja se istodobno temeljito transformiraju“ (str. 11), a na nacionalnoj razini to su rat i njegove ekonomske i političke posljedice te loši rezultati (demokratizacija, gospodarstvo) društvene transformacije. S obzirom na obuhvaćenu skupinu mladih jasno je da su oni bili izravno zahvaćeni tim kretanjima i posljedicama tih događaja.

Prvo poglavlje pokriva temu i podatke vezane uz socioekonomski položaj mladih. Razmatra se niz komponenti koje predstavljaju osnovicu za razvoj obrazovnih i profesionalnih kapaciteta i u konačnici rezultate koje bi mogli postići. Kreće se od obitelji, koja predstavlja izvor financijskog i socijalnog kapitala te njezina utjecaja na izbore, iskustva i potencijalne prilike. Uzimajući u obzir obrazovanje oca, obrazovanje mladih te povezujući ta obilježja s njihovim socioprofesionalnim statusom, brojem članova kućanstva, prosječnim izdacima kućanstva, statusom kućanstva u kojem Žive, pristupom tehnologiji i knjigama, vidljivo je da postoji „tendencija reprodukcije u današnjem hrvatskom društvu uz segregaciju u pristupu obrazovanju i ekonomskim resursima" (str. 28). Iz prikazanih rezultata jasno je da resursi koje obitelj ima na raspolaganju te razina obrazovanja oca predstavljaju snažne preduvjete da i mladi iz takvih obitelji postižu više obrazovne uspjehe, a i sami imaju više resursa, pristup tehnologiji i snažniji socijalni kapital.

U drugom poglavlju autorice se koncentriraju na obitelj i socijalne mreže kojima su mladi okruženi i u kojima sudjeluju. Promatrajući obitelj, odnose unutar obitelji i stavove o budućim preferencijama mladih vezano uz tu temu, dolazi se do zaključka da je obitelj i dalje glavni oslonac mladima, da ima visoku važnost te većina mladih živi upravo u toj zajednici (više od 60\%). Uz to, unutar obitelji vladaju skladni obiteljski odnosi te većina mladih svoju budućnost vidi u bračnoj zajednici i osnivanju obitelji. Međutim upravo kod odabira bračnog partnera vidljiva je i tradicionalnost mladih u Hrvatskoj te je visok udio onih kojima su bitna vjerska, regionalna i nacionalna pripadnost te odobrenje roditelja.

Treće poglavlje donosi rezultate vezane za obrazovanje, zapošljavanje i mobilnost mladih. Iz njih je vidljivo da mladi iskazuju tendenciju ka pohađanju javnih visokoškolskih ustanova, i to većinom u Hrvatskoj, a i dvije trećine njih upisali su ili smatraju da će upisati željeni studij. S tim u vezi treba naglasiti i da je velika većina njih u određenoj mjeri zadovoljna sustavom obrazovanja u državi. Vezano uz zaposlenje, većina njih želi imati siguran posao i egzistenciju te se manje vode profesionalnim motivima. Uz to, preferiraju zaposlenje u javnom sektoru, što je zasigurno usko povezano s prethodno spomenutim aspiracijama ka sigurnosti. Posebno zanimljiv podatak vezan je uz želju za iseljavanjem mladih u inozemstvo. Naime čak ih je 70\% 
izričito reklo da to ne želi. To pokazuje iznimno veliku promjenu u odnosu na 1999. godinu kada ih je 61\% imao želju za iseljenjem. Niska mobilnost mladih očita je i u pogledu preseljenja unutar Hrvatske te i u ovom slučaju 70\% mladih nema tu želju.

U četvrtom poglavlju pokrivene su teme koje se odnose na slobodno vrijeme i rizično ponašanje mladih. U dijelu koji se tiče slobodnog vremena vidljivo je da ga mladi uglavnom provode kroz druženja i razonodu, a manjim dijelom uz sport i knjige te da internet preuzima primat među medijima. Među ispitanicima stavlja se veliki naglasak na izgradnju osobnog stila, što je vidljivo i kroz troškove koje ostvaruju (na vrhu su odjevni predmeti, izlasci i telefon/mobitel), ali i kroz rang-ljestvicu pojava koje su u modi, a na čijem su vrhu dobar izgled, karijera i neovisnost. Po pitanju rizičnog ponašanja treba istaknuti pad konzumenata duhana, ali i konstantu među onima koji konzumiraju alkohol. To pokazuje i općenitu sliku prihvaćenosti tj. neprihvaćenosti tih aktivnosti u društvu. Uz to, rizično ponašanje mladih očigledno je i kroz povezivanje spolne aktivnosti (više od 60\% je spolno aktivno) i prakticiranja spolno neodgovornog ponašanja (kontracepciju redovito koristi malo više od trećine mladih). Zaključno u ovom dijelu treba naglasiti i nisku toleranciju mladih prema homoseksualnim osobama. Tako je moguće „prepoznati skupinu mladih koja zastupa tradicionalan sustav vrijednosti, a čiji je socijalni profil uglavnom određen nižim stupnjem obrazovanja, pretežno ruralnim rezidencijalnim statusom i razmjerno niskim socijalnim porijeklom" (str. 88), a ta je skupina i relativno brojna (30\%).

Peto poglavlje obuhvaća podatke o socijalnom povjerenju i vrijednostima mladih. Rezultati su pokazali da mladi pokazuju najviše povjerenja prema članovima obitelji i prijateljima, što je pokazatelj povezujućeg socijalnog povjerenja. S druge strane, premošćujući socijalni kapital pokazao se kao iznimno slab. Kao najcjenjenije vrijednosti među mladima ističu se dostojanstvo, borbenost i tolerantnost. Međutim kada je u pitanju prihvaćanje različitih društvenih skupina, tada se ističe nizak stupanj tolerancije prema Romima, homoseksualcima i obiteljima iz balkanskih zemalja, a prema prihvaćanju etničkih skupina najmanje su među mladima prihvaćeni opet Romi te Albanci i Srbi. Potrebno je istaknuti i izostanak volonterskog rada među mladima, koji je jedna od dimenzija socijalnog kapitala. Njih 40\% je zainteresirano za volonterski rad, ali samo je 13\% sudjelovalo u nekom njegovom obliku u posljednjih 12 mjeseci. U konačnici, po pitanju religioznosti može se primijetiti visok postotak vjernika, a među njima je najviše onih koji religijske prakse upražnjava kroz slavljenje vjerskih blagdana, dok je intenzitet prakticiranja religije kroz ostale prakse znatno niži.

Posljednja dva poglavlja orijentirana su na političku i ekonomsku dimenziju. Šesto se poglavlje bavi politikom, razvojem i demokracijom. Rezultati iz tog poglavlja pokazuju da se Hrvatska ne razlikuje od ostalih društava, ali i to da su u skladu s prethodnim istraživanjima kod nas. Vidljiva je mala zainteresiranost mladih za političke događaje i slaba participacija u izbornim procesima. Uz to, pokazuju nezadovoljstvo generacijskim političkim predstavništvom, stanjem demokracije u zemlji te mogućnostima osobnog utjecaja na tijela vlasti. Indikativno je i da je obitelj kao izvor informiranja o političkim događajima na prvom mjestu samo kod 25\% mladih te da više od $60 \%$ njih nikada ili rijetko razgovara s roditeljima o političkim događajima. 
Po pitanju gospodarstva mladi su umjereni optimisti u pogledu budućnosti Hrvatske te izrazito optimistični vezano uz osobnu budućnost.

Posljednje poglavlje stavlja naglasak na Hrvatsku i Europsku uniju kao novo okruženje u kojemu se mladi nalaze. Vidljivo je da put ka europskim integracijama ima umjerenu potporu i da više povjerenja pokazuju prema institucijama EU-a nego prema domaćim političkim institucijama. Međutim ne može se istaknuti postojanje snažnijeg eurooptimizma, i to posebno iz razloga što mladi u podjednakoj mjeri očekuju i poželjne i nepoželjne posljedice koje Hrvatskoj ulazak u Uniju donosi.

Smatram da knjiga pruža izniman doprinos i temelj za mnoga područja. Taj je potencijal vidljiv u dvama bitnim aspektima: a) teze i podaci za daljnja istraživanja, b) javne politike i zakoni. Kao što je već u uvodu spomenuto, Shellova se istraživanja provode u nizu zemalja, te podaci koji su dobiveni za Hrvatsku definitivno trebaju biti iskorišteni za daljnje komparativne analize s drugim zemljama te za longitudinalne analize kada je u pitanju Hrvatska. Uz to, postoji i niz rezultata koji su se, prema riječima autorica, pokazali kao neočekivani ili onih koje ce ostatak znanstvene zajednice željeti dodatno ispitati ili pojasniti. Istaknuo bih neke rezultate koji su potencijalno zanimljivi - rezultati pokazuju da mladi u Hrvatskoj nisu skloni nasilju i nasilničkom ponašanju (iako u javnom mnijenju prevladava upravo suprotno mišljenje), 70\% mladih ne koristi nikakve privatne instrukcije (iako se u javnosti stvara dojam da je ta pojava puno raširenija, ali isto tako trebalo bi vidjeti kakvi su trendovi), ispitanici koji su završili trogodišnju (strukovnu) školu ne razlikuju se po količini praktičnog rada u odnosu na ostale ispitanike te je samo $4 \%$ mladih nezadovoljno svojim izgledom (iako se opet često sugerira suprotno).

Nadalje, podaci i zaključci predstavljeni u knjizi trebaju i već jesu korišteni kod kreiranja različitih javnih politika. Naime novi (još nedoneseni) Nacionalni program za mlade i plan implementacije Garancije za mlade koristili su podatke dobivene ovim istraživanjem, ali oni su korišteni i kod donošenja zakona, što je već bio slučaj kod Zakona o mladima. Uz to, s obzirom na prethodno spomenute podatke o spolno rizičnom ponašanju, konzumaciji alkohola i duhanskih proizvoda, izostanku komunikacije o političkim događajima u obitelji te razini netolerancije prema različitim društvenim skupinama, pokazuje se neophodnim korištenje ovih nalaza za izradu i zagovaranje empirijski utemeljenih javnih politika i različitih oblika obrazovanja mladih (zdravstveni odgoj i građanski odgoj). Upravo taj aspekt knjige smatram njezinim najvećim i najpozitivnijim doprinosom. Jasno je izdiferencirano koje skupine mladih s obzirom na obrazovanje, dob, socioekonomski status i ostale pokazatelje imaju određene sklonosti, te se može prepoznati gdje i kako treba djelovati kako bi se povećala tolerancija, politička pismenost i smanjilo rizično ponašanje. Međutim isto tako podatke je moguće koristiti i u drugim područjima, primjerice u pristupu obrazovanju ili politici zapošljavanja.

Vezano za negativne strane koje se mogu pronaći u knjizi, treba istaknuti dobnu skupinu koja je obuhvaćena istraživanjem. Istraživanjem su obuhvaćeni mladi od 14 do 27 godina. Problem leži u tome što ostala Shellova istraživanja obuhvaćaju mlade od 12 do 25, a nacionalna su istraživanja obuhvaćala skupine od 15 do 29 godina. 
Takav uzorak može stvarati probleme pri komparativnim i longitudinalnim istraživanjima. Naravno, i dalje je moguće pratiti određene trendove i uspoređivati rezultate. Uz to, smatram da bi malo obuhvatniji prikaz nacionalnog konteksta u analizi dao dodatnu vrijednost i podigao zanimljivost knjige. Iako tema jest kontekstualizirana, vidljivo je da je prvenstvena namjera autorica bila predstavljanje podataka.

Nikola Baketa 